\title{
RHYTHMIC PATTERN OF LONGSHORE BARS RELATED TO SEDIMENT CHARACTERISTICS
}

\author{
Masash1 Hom-ma and Choule Sonu \\ Department of C1vil Englneering, University of Tokyo \\ Tokyo, Japan
}

\section{INTRODUCTION}

Despite a number of valuable contributions by many predecessors, namely F. P. Sbepard (Ref. 1) and $G$. H. Keulegan ( $R \in f .2$ ), our knowledge regarding the effect of a longshore bar on the sedimentary process of a coast has long remained a plausible, qualitative understanding that a longshore bar constitutes a zone of active migration of bottom deposit due to agitation of breakers and currents. Th1s was probably due mainly to the difficulty of performing an accurate hydrographic survey near the breaker zone. On the other hand, the geometrical character 1otics along a single bar profile, which was sounded off elther from a stable pler (Ref. I) or a suspended cable (Ref. 3) resulted in a hopeless scatter.

An aer lal photograph, if taken under favorable conditions, may show an interesting picture of aubmerged topographies in a distinct contrast made by the bright tone of a shallow bar crest or a shoal, against the dark background of a deep trough or a rock bottom. By comparing such photographic records with convenient soundings derlved from some of the Japanese coasts, an interesting topographical feature of a longshore bar has been disclosed. A longshore bar may attain a rhythmic pattern consisting of echelons of arcuate (or lunate) bar unit, which in entire appearance strongly resembles that of a honejcomb.

It has also been discovered that a $r$ hythmic bar pattern is correlated with other important factors either dynamic or atatic, which participate in the general processes of a coast, namely the shoreline conflguration, the shoreface slope and deposit, the topographies on the offshore bottom, transformation of incident waves, the longshore currents and the littoral drifts. The authors have further attempted to develop a hypothetical concept on the origin of littoral rhythms as well as the behaviors of alongshore movement of sediment, and to consider their englneering impli- 
cations on the basis of such findings.

Although our success whlch has been achieved so far is yet incomplete due to lack of avallable data, it is belleved that the approach and concept as proposed in the present paper may suggest an encouraging Iine of researcb toward formulatine a unified macroscoplc view on the mechanics of the ilttoral process.

\section{LONGSHORE BAR PATTERNS}

\section{RHYTHMIC BAR PATTERNS}

Fles. I - 5 show reproduction from aerial photographs which were taken over the Japanese coasts. An outstanding feature which is common to these plctures is that the crests constitute an assembly of arcuate units which are arranged in successive echelons of different spacings depending upon the distance from the shoreline. These places, equally located very close to a river mouth, are known for predominant action of littoral drift along the shoreline. It is recognized that the fartber offshore, the longer the spacing of an arcuate unit tends to become. The bar ec helons are not completely separated from each other. The feet of the outer units join those of the inner ones producIng a wide shoal there due to broadening out of the bar crests. This shoal extends toward inshore, frequently at oblique angles, as far as the shoreline, where again the feet of the innermost bars join the interior topography, the shoreline. We notice a remarkable feature that where the ber group of the innermost echelon is merged with the shoreline there exists a slight outward projection of the beach.

Thus, a beach which is confronted with a rhythmic bar system is usually marked by a series of an orderly indentation baving the inter-apex spacing essentialiy similar to that of the offshore bars and apparently greater than that ordinarily found with a beach cusp.

Such a striking combination between longshore bars and shoreline conflguration will be seen, in the chapters to follow, to represent the basic rhythms which govern in effect the overall characteristics of other factors elther consplcuous or so minute that they may otherwise evade our attention as mere irregularities.

OCCURRENCE OF BAR RHYTHMS

A sorutiny of extensive phtographic evidences derived from nearly entire stretch of tbe Japanese 
COASTAL ENGINEERING

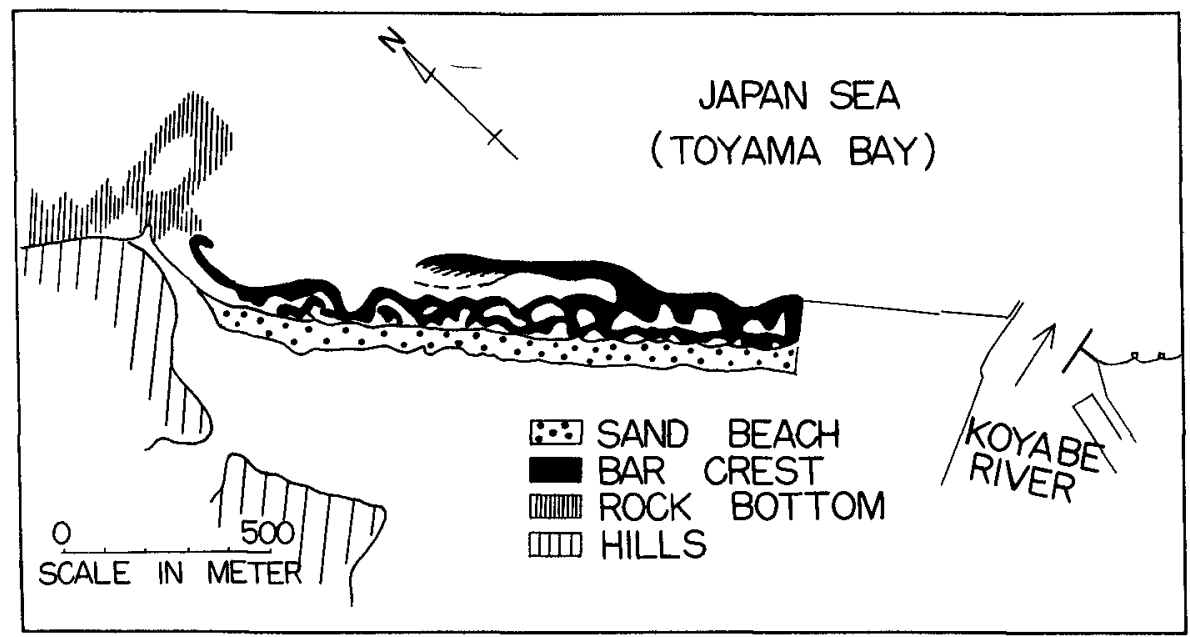

F1gure 1. Rhythm1c bar pattern, near Fushik1, 1961. (by courtesy of Japan Googr. Inst.)

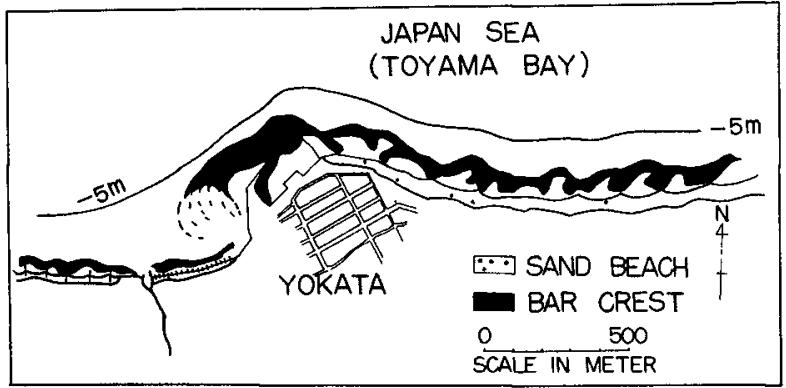

F1gure 2. Rhythmic bar pattern, Yokata, 1961. (by courtesy of Japan Geogr. Inst.)

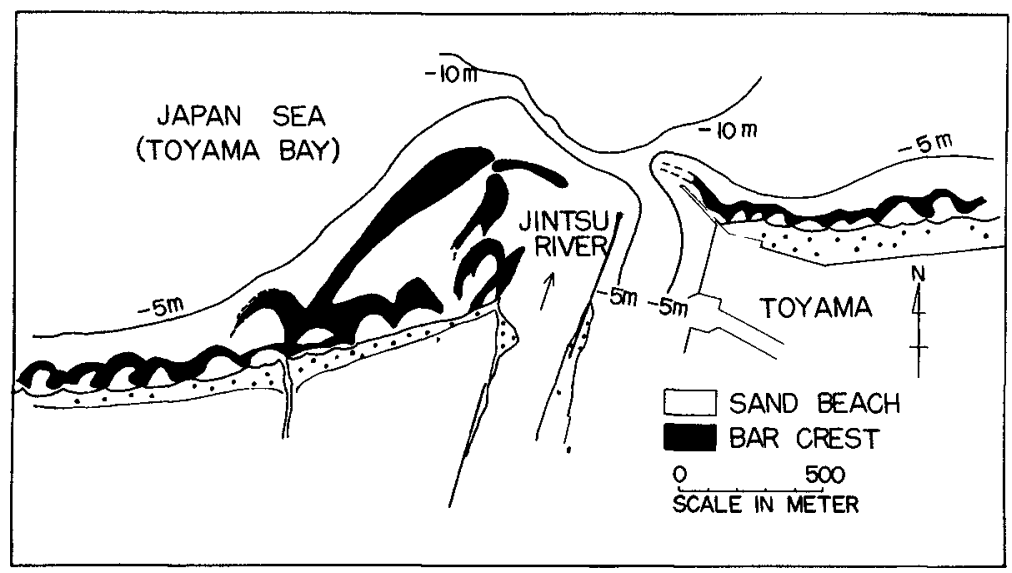

F1gure 3. Rhythmic bar pattern, Jintsu, 1961. (by courtesy of Jap. Geogr. Inst.) 
RHYTHMIC PATTERN OF LONGSHORE BARS RELATED TO SEDIMENT CHARACTERISTICS

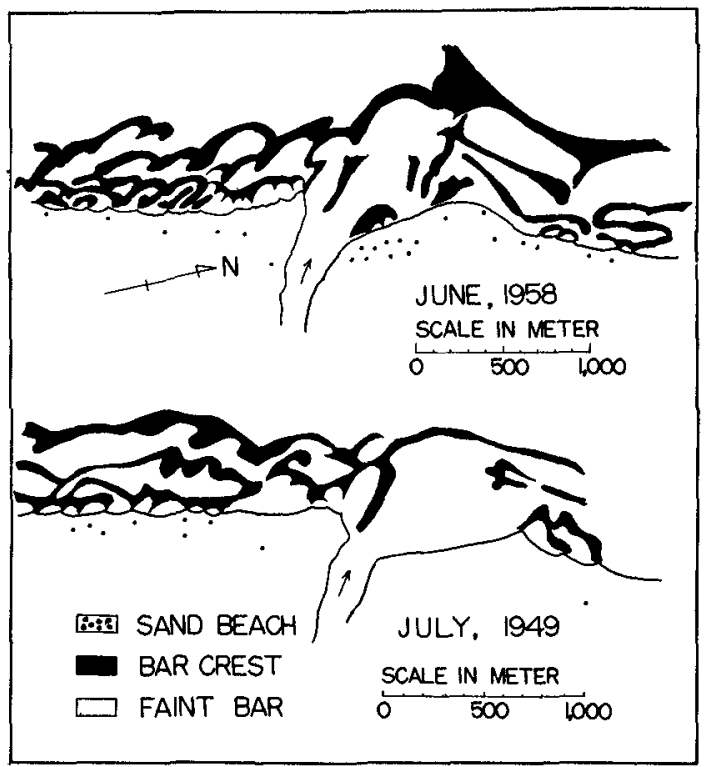

F1gure 4. Rhythmic bar patterns of 1958 vs. 1949, Shin-sbinano. (by courtesy of Jap. Geogr. Inst. and N11gata Prefecture)

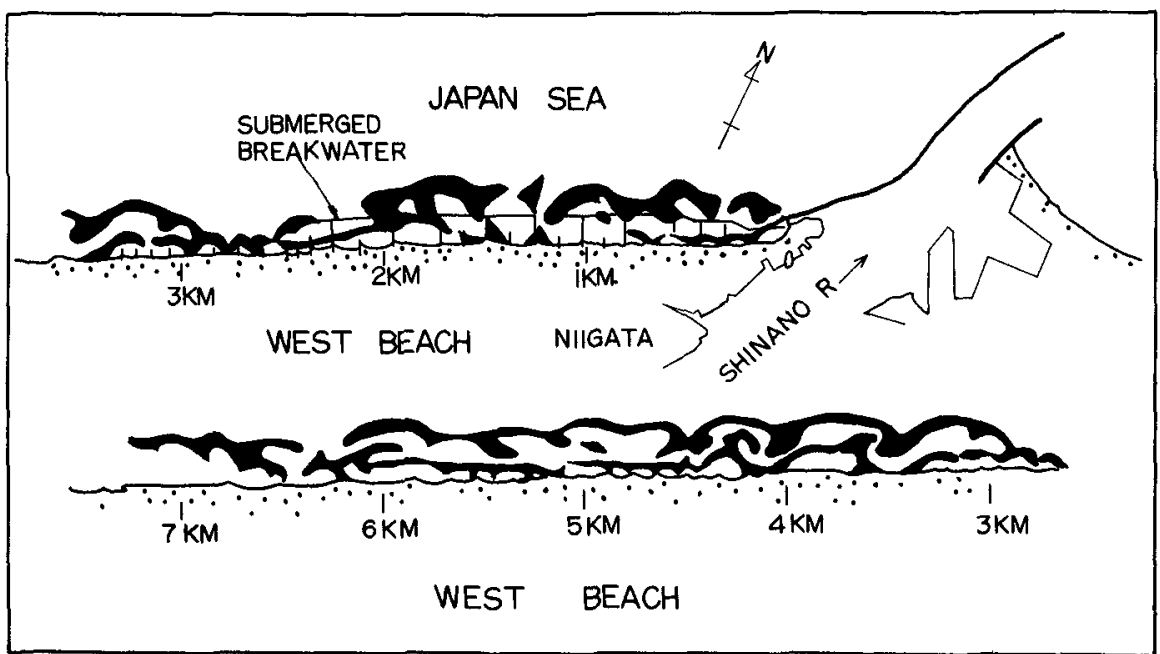

F1gure 5. Rhythmic bar pattern, N11gata west beach, 1958. (by courtesy of N11 gata Prefecture) 


\section{COASTAL ENGINEERING}

coasts shows that a rhythmic bar system may occur at localities where some fundemental requirements are satislied. Primarlily, a beach must be close to a rich source of supply. Secondly, the bottom must be sufficiently gentle in the shallow water zone. The local wave conditions merely affect the magnitude of predominant rhythms. The nature of bottom deposit is likewise ruled out as insignificant; the $r$ hythmic bar pattern has been discovered not only on a sandy beach but also on a ravel beach. Therefore, the beaches lying close to a river mouth are frequently marked with ber rhythms. On the other hand, a beach skirting a sharply descending alluvial fan is often devold of either a rhythmic bar or, on some occations, even a sign of a stralght bar, although a shoreline indentation may still exist. Consequently, a delta beach adjacent to an estuary is the most likely place for occurrence of bar rhythms.

Fig. 6 demonstrates such an example. Along the eastern half of the Toyama Bay coast which is found at the rim of a eroup of alluvial fans of the Kurobe and other rivers, the bottom slope is as great as $4 \%$ down to the depth of $-10 \mathrm{~m}$ and $20-15 \%$ down to $-100 \mathrm{~m}$, while along the delta beach westward from the mouth of the Joganjl river the bottom slope becomes gentler, falling to $2-0.8 \%$ down to $-10 \mathrm{~m}$ and $3-2 \%$ down to $-100 \mathrm{~m}$. The photographic evidences show that it is only at the western half of the Toyama Bay coast that a $r$ hythmic bar pattern is found to exist, while the eastern half of the same coast totally lacks in a bar of any noticeable size. The experiences of the autbors on the Japanese coasts show that a bottom slope of about $2 \%$ down to $-10 \mathrm{~m}$ is approximately the limit for occurrence of a rbythmic bar pattern.

In fact, the two requirements mentioned above may be summed up in one definitive condition that occurrence of a rhythmic bar pattern depends essentially on the extent to which the unconsolidated sediment on the nearshore bottom is subjected to significant agitation by wares. It is probably due to this reason that a rhythmic bar pattern is also found at a place which is located relatively far from a source of supply yet provided with a gentle bottom slope. Therefore, a source of supply must not always be a river. It may be an eroding beach where the sand supply is derived immediately from the regressing beach, or a tidal inlet where the alongshore component of sediment drift is intercepted over a shallow bottom near the shoreline by a transversal flush of tidal currents in and out of the inlet.

RHYTHMIC BAR VERSUS STRAIGHT BAR 


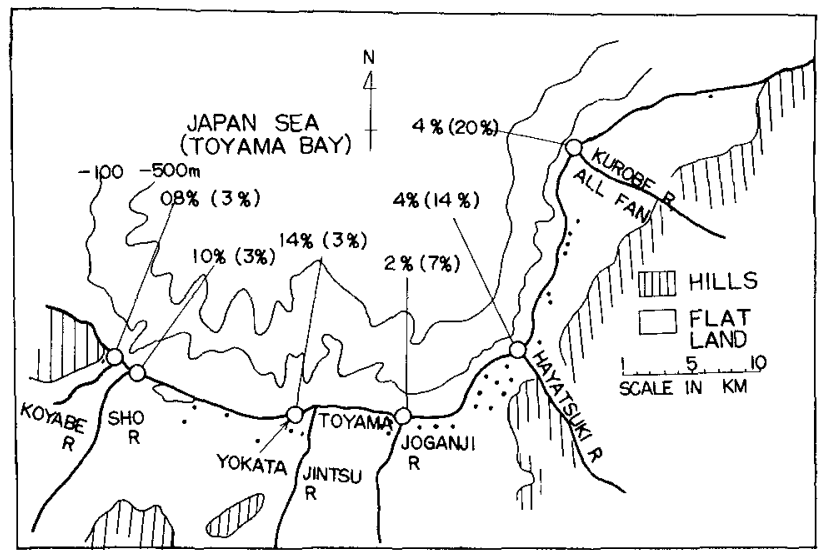

Figure 6. Bottom slopes along Toyama Bay coast. Attached figures out of and in parentheses Indicate slopes down to $-10 \mathrm{~m} \&-100 \mathrm{~m}$ each.

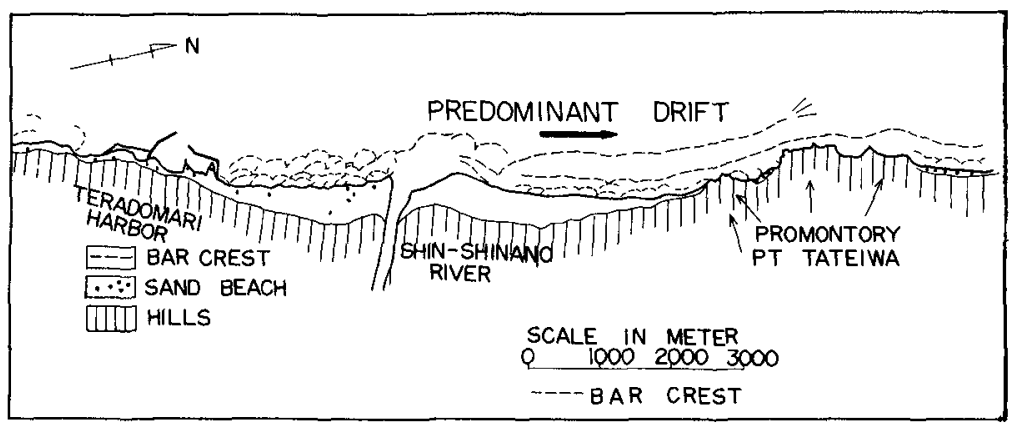

F1gure 7. Comparison of rhythmic and stralght bars at outlet of Shin-shinano, 1958.

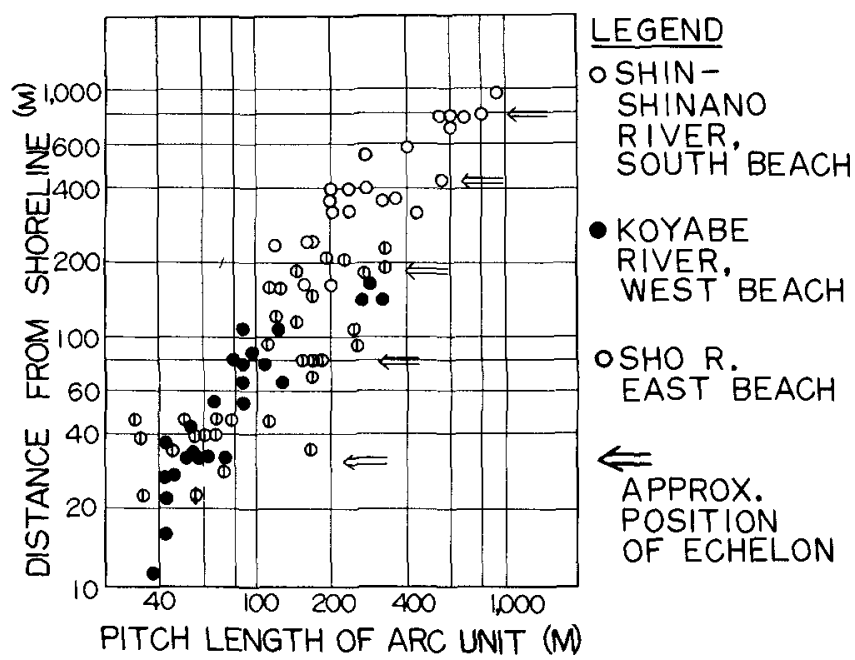

Flgure 8. S1ze of arcuate bar with distance from shore. 


\section{COASTAL ENGINEERING}

A straight ber is encountered almost on any type of sandy beach, unless the bottom slope 1s too steep, say below about 2 down to the depth of $-10 \mathrm{~m}$.

What are the physical properties which distinguish these two types of bars? on the beaches cited in Figs. 1 - 5, we find the rhythmic bars more pronounced on the updrift side of the source of supply than on the downdrift side. According to Fle. 7, along the beach of the Shin-shinano river the bars are largely stralght on the downdrift side. It is interesting to recognize here that the middle echelon, a stralght bar, continues to extend on the rocky bottom around the promontories and into a sandy bottom lying further nortb, while the innermost echelon which consists of rhythic bars is absorbed into the sandy beach just short of Pt. Tateiwa, the flrst of the three promontorles in thls area. On the updrift side the rhythmic bars also fall to detour the rock bottom in front of the Teradomart harbor.

Summing up these evidences, we are inclined to presume that a stralght bar may indicate the presence of a strong uni-directional drift of bottom deposit, which is so active that it may transport sediment even beyond promontorles through a well-deflned zone on the rock bottom without undergoing appreciable diffusion midway; while the rhythmic bar may rather imply a stagnating pattern of alongshore drift in which the bottom deposit is preserved more or less in a self-contained system of equilibrium. In fact, such an assumption seems lergely allowable, for, as we will see later in the discussions on the movement of littoral rhythms, the rhythmic pattern of coastal topographies would not move an appreclable distance along the shoreline. However, in view of 1 ts heavy implications on the fundamental problems of coastal sediment, thls polnt must not be emphasized without further evidences.

\section{TOPOGRAPHICAL PROPERTIES OF RHYTHMIC BAR}

\section{TYFES OF BAR RHYTHMS}

Fig. 8 gires a general relationship between the unit size of bar rhythms and the position of echelons, each expressed in terms of spacing between both feet of $\theta a c h$ arcuate unit and the distance of the arc center from the shoreline, respectively. Data have been read off from the aerlal photographs on the west coast along the Toyama Bay and the south beach at the shin-shinano river, where the bottom slope down to a depth of $-10 \mathrm{~m}$ 18 approximately 1 \%.

The unit size of a bar rhythm is almost uniform 


\section{RHYTHMIC PATTERN OF LONGSHORE BARS RELATED TO SEDIMENT CHARACTERISTICS}

within the same echelon, but varies to an appreciable degree by echelon and also by locality. The average unit $912 \theta$ for each echelon, shown in the ordinate of Fig. 8, seems to increase by the doubling process, say $s \times 20, s \times 2^{1}, s \times 2^{2}, \ldots$, and $s \times 2^{6}$ in tho order toward offshore, in which the most appropriate value for the basic multiplicand $S$ will be $40-50 \mathrm{~m}$ on the beaches treated here. The value of $S$ may vary by loca$11 \mathrm{ty}$, mainly in accordance with the regional predominance of wave conditions.

The shape of an arcuate unit is not necessarily symmetrical. It is skewed toward the predominant drift direction on all the beaches c1ted bere. The skew may be attributed to the predominant wave incidence or direction of longshore currents. According to shepard (Ref. I), rip channels w1Il be formed on the bottom of the surf zone. However, this is obviously unable to affect the overall bar system for a durable perlod of time, bocause it is a passing topography with a lifo span of merely a fow weoks. On the other hand, coastal structures may affect the shape of an arcuate rhythm of a bar to an appreclable extent, depending upon the magnitude of a structure as well as the nature of a bar. For Instance, on the Nilgata west beach (FIg. 5) where part of the shoreline is protected with a submerged breakwater and a series of groins in order to prevent orosion, the bar rhythms are disfigured considerably, particularly near the protected shoreline.

\section{PROFIIES ACROSS A RHYTHMIC BAR}

Fig. 9 shows a bottom topography of the Nilgata west beach whlch was obtained by a sounding, together with a rhythmic bar pattern traced from an aerial photograph. There is a lag of one month between these data; however, 1 t may not 1mpalr the usefulness of th1s comparison since no slenificant ware action took place in the mean time.

According to Flgs. 9 and 10, a correlation betweon the rhythmic patterns of a bar and the perpendicular bottom profiles is well defined, and our previous observation is confirmed that the foot of an arcuate unit corresponds to a shoal, while the center of the arc to a deep trough and a steep bottom slope in the surf zone. This fundamental relationshlp has also boen recognized on the beach of Tokal, Japan, which is exposed to the sea and swell of the Paciflc ocean and frequently subjected to extremely violent waves due to a typhoon. The shoal may become so shallow that on some occasions it is wadable. The authors have encountered such an example at the gravel beach of the Ishikawa 


\section{COASTAL ENGINEERING}

Prefecture, where the bathing cbildren walked over this shoal to play on the crest of an offahore bar. Here the crest of the bar rose to a depth of about $1.5 \mathrm{~m}$, while the trough was about $3 \mathrm{~m}$ deep.

\section{BAR RHYTHMS VERSUS NEARSHORE TOPOGRPHIES}

\section{TYPES OF SHORELINE RHYTHMS}

Blbl lographies are replete on the subject of beach cusp since the days of D. W. Johnson (Ref. 4). However, it has been only in recent years that the rhytbmic undulation having a greater inter-apex spacing than that of an ordinary beach cusp has been given a serlous attention.

Per Bruun (Ref. 5) recognized from investigation of the nearshore topographies along the Danish Nortb Sea coast tbat tbese "shoreline waves" mlerated alongshore as if they were a mass of land at a varlable rate between 0 and $1,000 \mathrm{~m}$ per year. According to his measurement the spacing ranged between 300 and $2,000 \mathrm{~m}$, whlle the amplitude between 60 and $80 \mathrm{~m}$. Discussing on the orlgin of such a shoreline rhythm, he describes: "there may be some conniection between the migrating undulations and breaches in the longehore bar, possibly due to erosion by rip currents because the wave trough is often formed behind a breach and the crest just ahead." He further pointed out that the rhythms ("humps") were also present on the offshore bottom along the same coast.

On the other hand, 0. F. Evans (Ref. 6) made studies on the beach cusps, including a large undulation, on the southern beaches of the Lake Mlohlgan. According to him, the beach cusp may be classifled into five different categorles, of which the significant types of natural origin are:

(1) "very large capelike cusps (or undulations) formed during storms along the beaches that are susceptible to considerable erosion and deposition."

(2) "large cusps (undulations) whicb have their apexes continuing out into the lake as a ridge of sand on the lake bottom."

(3) "ideal cusps whtch usually occur in series and come nearest of all to being evenly spaced."

sccording to his measurement, the "very large capelike cusps", which apparently are equivalent to Bruun's shoreline wave of tbe order of $103 \mathrm{~m}$, are spaced within the range from 96 to 1,050 feet, the average being 296 feet allowing for an appreclable scatter. The "largo cusps", the second largest of his classiflcation 


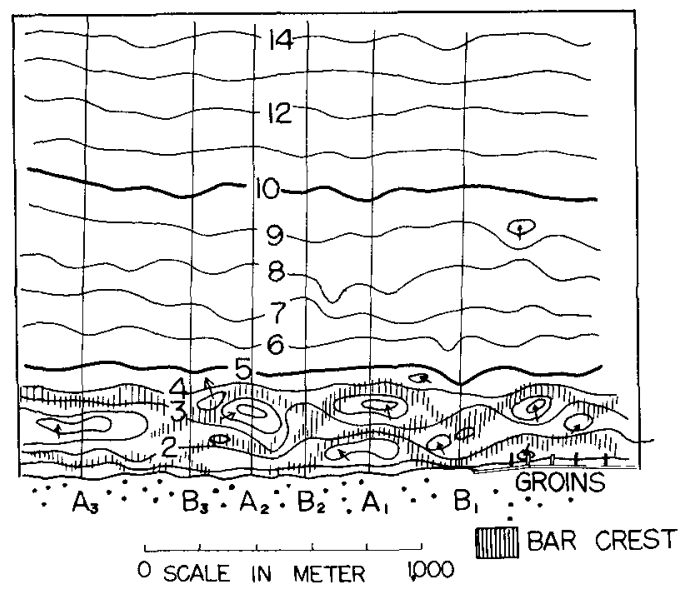

Figure 9. Nearshore topography shown with bar positions, Nilgata west beach, 1958 .

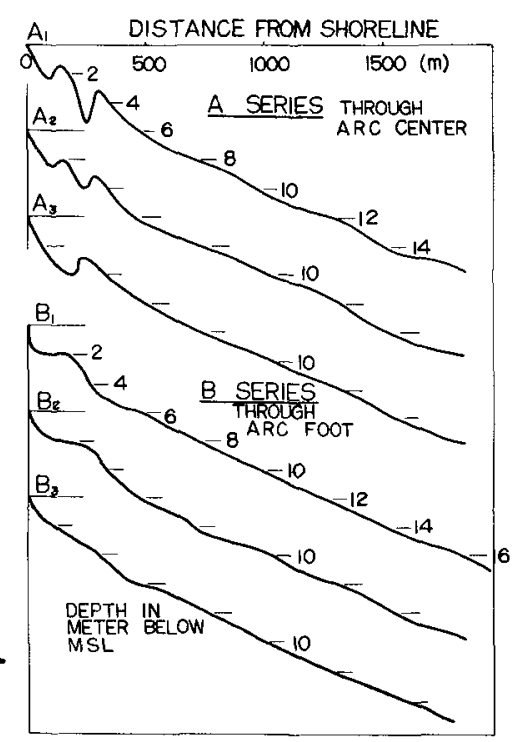

Flgure 10. Perpendicular bottom profiles across bar crests and shoels, Nilgata west beach. (Cf. Fig. 9)
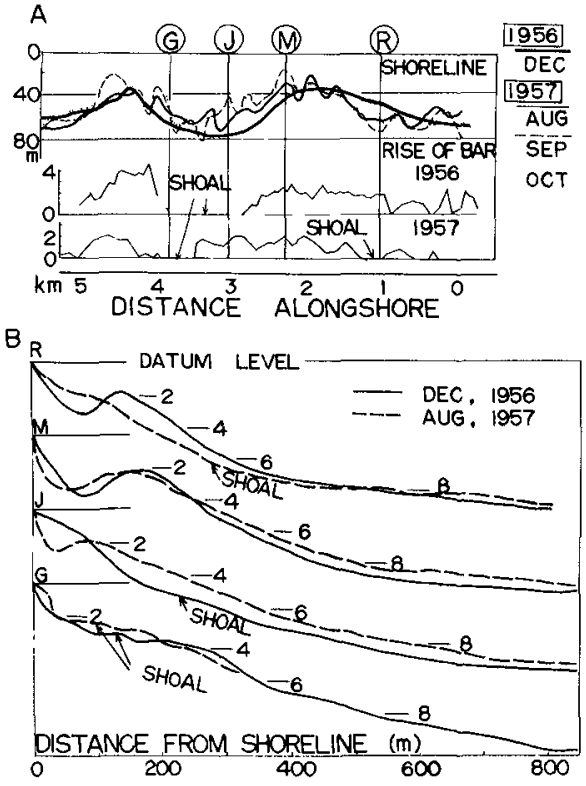

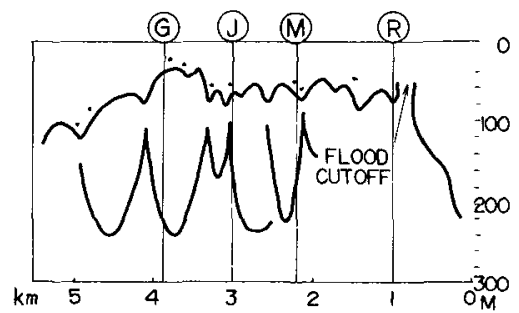

Flgure 12 .

Bar rhythms reproduced from aerlal photograph, 1961. (by courtesy of Jap. Atomic Gener. Co.)

F1gure 11. Shoreline A. Shoreline rhythms compared with bars. (reproduced from Moel, Ref. 8)

B. Perpendicular bottom proflles across bar crests and shoals, Tokel beach, Japan. 
equivalent to Bruun's wave of the order of $10^{2} \mathrm{~m}$, have also uneven spacings ranging from 33 to 102 feet with the average being 69 feet. However, the scatter of spacing is improved to a considerable degree with this cusp as compared with the capelike cusp. Finally, the "1deal cusps" are the best graded in the inter-apex spacing of the three categorles, ranging from 0.9 to 34.5 feet.

He also described the nature of the foreshore bottom which was found to occur in particular connection with these different shoreline rhythms. As for the large capelike cusp, "the underwater terrace slopes gently and has on 1 t an excess of sand down to a depth of several feet." The capelike cuspate projection. results from alternate accretion and erosion of such an accldental deposition on the shallow bottom due to changing conditlons of waves and currents. On the other hand, the large cusps are always accompanied by thelr ridges called "ball and low." He admited further that "where the ends of the ridges join the shore,... the Increase in the supply of sand at the shoreline results in the formation of ( $t$ bis type of) cusp." Apparently, this transversal ridge is ldentical to the nearshore shoal whlch, as we have already recognized from the aerlal photographs (F1gs. 1 - 5), bridges the feet of a bar rhythm and the corresponding outward projection of a shoreline. As for the $1 \mathrm{deal}$ cusps, however, he does not seem to have recognized any consplcuous topography on the corresponding foreshore bottom, except that their occurrence appeared to depend on the breaching of a (Iongshore) ridge. The relationship between the 1deal cusp and the foreshore bottom has been somewhat better descrlbed by $\mathrm{Ph}$. H. Kuenen (Ref. 7 ), who remarks that In front of the embayments the foreshore 18 sometimes bullt out under water in a delta shapo.

In Japan, A. Mog1 of the Japan Hydrographic Off1ce was probably the first to demonstrate the presence of regular rhythms on the shoreline conflguration. Fig. 11-A shows a partial reproduction from hls result based on the shoreline investigation at the northern half of the Tokal beach, Japan. According to bls measurement, the shoreline undulations found here consist of three different types of rhythms as tabulated below:

TABLE I. Dimensions of Shoreline Rhythms, Toka1, Japan.

\begin{tabular}{|l|l|l|l|}
\hline class & largest & medium & smallest \\
\hline spsolng & 2,000 & 300 & $30-60 \mathrm{~m}$ \\
\hline amplitude & $40-50$ & $20-30$ & $10^{\circ}$ order m \\
\hline
\end{tabular}


In nature, these three types of rbythms are superposed on one another, each slightly skewed toward the predominant direction of littoral drift. He also recognized that the largest rhythms are associated with the geometrical properties of the longshore bar, 1.e. that the apex and embayment are found behind the breaching and the center of a longshore bar, respectively. This finding seems just the contrary of what Dr. Bruun has previously discovered on the Danish North Sea coast, if we should interpret the term "breach" as used by him to mean a shoal which lies in the gap of a continuous bar.

The present authors have also recognized regular $r$ hythms on the undulating configuration of a shoreline from aerial photographs as well as sounding data in Japan. Figs. 12 and 13 show such examples. Fig. 12 shows reproduction of an aerial photograph of the Tokal beaoh, whlch was taken in July, 1y6l, roughly three years after the beach investigation of Dr. Nogl, where the perpendicular scale has been exaggerated to help visualization. By comparing Fle. 12 with the preceding Flg. 11-A, we note a strlking coincldence between the rbythmic phases of 1957 and 1961, each measured three years apart, although in $1 y 61$ a medlum-sized rbythm of about $800 \mathrm{~m}$ in spac ing occurred individually on the southern end of the beach.

Fig. 13 has been derived from the Nilgata west beach. Here also, we recognlze several types of shoreIine rhythms, as classified in the table below:

TABLE II. Dimensions of Shoreline Rhythms, Nilgata.

\begin{tabular}{|l|c|c|c|c|}
\hline Class & I & II & III & IV \\
\hline Spacing & $\begin{array}{l}7,000 \text { or } \\
\text { greater }\end{array}$ & 3,000 & $200-300$ & $10^{1}$ order \\
\hline Amplitude & 40 & 30 & 20 & 10 order \\
\hline
\end{tabular}

unit : meter

The $r$ hythms of the order of $30 \mathrm{~cm}$, measured at one-year interval, fit surprisingly well to each other, although those of greater orders show some appreciable amount of perpendicular displacements due possibly to active beach erosion which has long been in progress bere. (see fle. 13-B) Since our range of survey is limited only to 7 $\mathrm{km}$ along the shoreline, there is no way of asserting whether or not the greatest rhythm, Class I, having a spacing as ereat as or greater than $7,000 \mathrm{~m}$, could be actualiy present in nature as a repeating phenomenon. In fact, this might have been brought about by scour at the foot of a long river jetty where the converging waves produced a large embayment. (See also Fig. 5) 
It is often very difficult to recognize a shoreline rhythm beyond the order of $10^{3} \mathrm{~m}$ in spacing either from an aerlal photograph or by inspection in the fleld, since it may merely represent the general trend of a group of lesser rhythms of the order of $10^{2} \mathrm{~m}$ and less. Only by convenient exaggeration of an accurate sounding data becomes such a long-range undulation sufficlently not1ceable. On the other hand, the best deflned of these varlous rhythms on the N11gata west beach is that belonging to Class III, which has the average spacing of 325 m, apparently a counterpart to the medium $r$ hythm found at the Tokal beach. Th1s average was taken from 60 such $r$ hythms which were observed by three successive surveys conducted approximately at one-year interval. The type of sample distribution is roughly Folssonian, having the mode value exactly at $300 \mathrm{~m}$ and a negliglble scatter by year.

\section{SHORELINE RHYTHMS ASSOCIATED WITH BAR RHYTHMS}

The predecessors in the subject of a shoreline rhythm as cited so far have equally polnted out a possibility, though to a varyling degree, that the shoreline rhythms may be connected with longshore bars. Dr. Mog 1 (Ref. 8) compared the phases of the shoreline rhythms with the alongshore distribution of the rise of $a$ bar, 1.e. the height of a bar crest above trough, on the Tokal beach, Japan. (F1g. 11-A) The apex of the greatest spacing of the order of 2,000 in was found to lie behind the breaching of a bar, while the embayment behind the center of each bar unit where the rise seemed most pronounced. It 1s surprising to note that this bar-shoreine rolationship is very strict, hardly variable oven if the entire system of rhythms are displaced along the shoreline. We see this feature by examining the bottom profiles across the bar and shoreline. (Fig. 11-B)

The survey 1 Ines $R$ and $J$ were both once close to an apex and once to an embayment, and on the bottom proflies were found once a shoal and once a bar, correspondingly. Along the survey line $M$, which was always closer to an embayment, we find a bar at all times. On the other hand, the survey line $G$ remained closer to an apex, and a shoal was always there.

The similar relationship between the shoreline and the bar holds with respect to smaller rhythms of the order of about $300 \mathrm{~m}$. Flgs. 14 and $15 \mathrm{glve}$ an example derived from the precision survey along a portion of the beach stretch of Fig. 11. We recognize that it is the inshore bar that corresponds to the shoreline rbythm of about $300 \mathrm{~m}$ in spacing, while the bar of the outer echeion corresponds to the shoreline rhythms of the order of about $2,000 \mathrm{~m}$. Unfortunately, due to limitation of accuracy in the surf-zone sounding as well as smoothing 


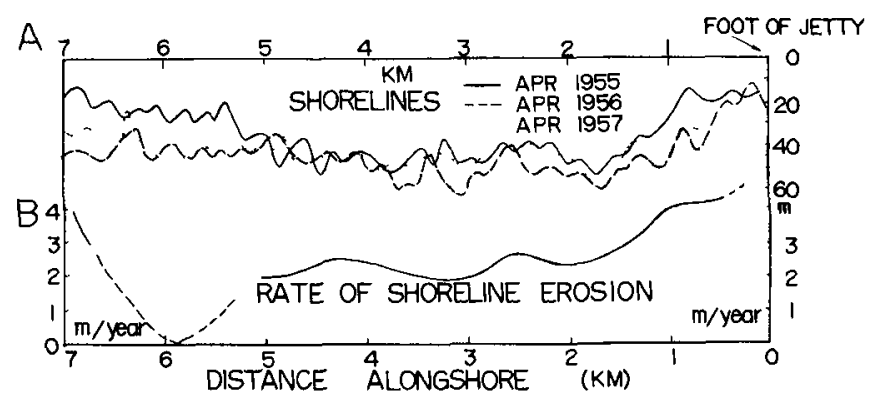

C PROGRESS OF COUNTER-EROSION WORKS SUEMERGED

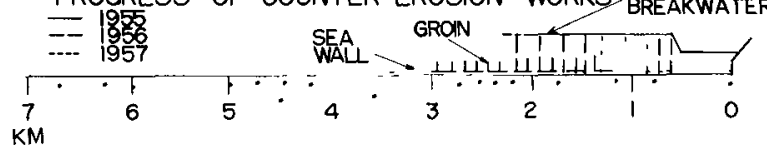

Figure 13. A. Shoreline $r$ hythms, N11gata west beach.

B. Rate of erosion averaged over past 10

- 20 years shows a rhythmic trend.

C. Progress of recent counter-erosion works.

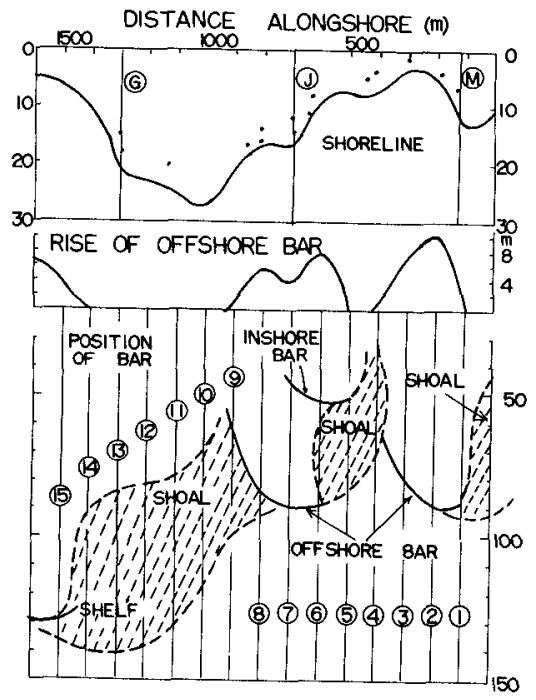

Figure 14. Shoreline and bar rhythms reproduced from sounding \& air photo.

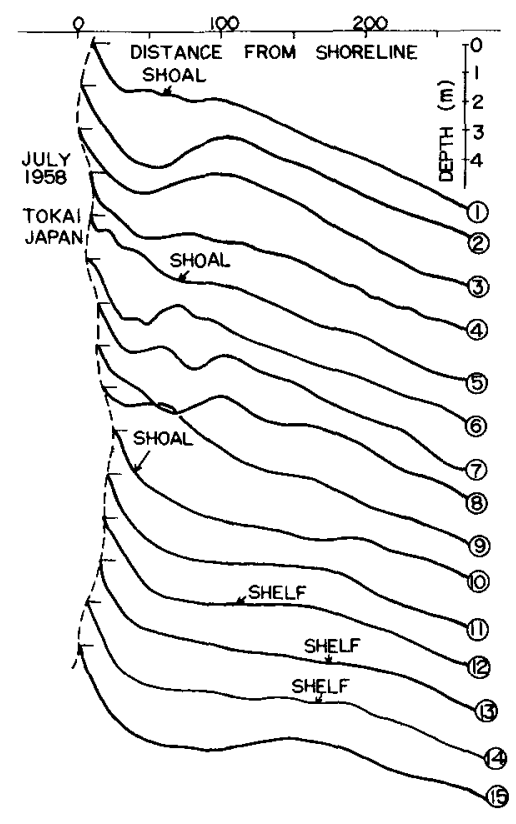

Figure 15. Bottom profiles along survey lines shown in Fig. 14, Tokal beach, Japan. 


\section{COASTAL ENGINEERING}

of the bottom features by summer swells, it is imposible to visualize the inshore bars from the sound ing map except as a broad shoal. Fies. 14 and 15 further confirm the result of our previous observation that the feet of an offshore shoal is continued toward inshore and in effect join the apexes of the shoreline rhythms as well as those of an inshore echelon. Where such a double merging occurs, there is an apex of a large undulation, while at an isolated foot of the inshore bar we find a less conspicuous apex of a smaller rhythm. Likewise, according to Fie. 16, which bas been reproduced from the result of Dr. MOEl (Ref. 8), the beach cusps, expressed in terms of inter-apex spacing, seem to correspond to their positions within the phase of a medium rhythm of the order of about $300 \mathrm{~m}$, although an appreciable scatter is also recognized. The limitation of sounding accuracy prevents us from tracing a minute feature on the foreshore bottom in relation to a beach cusp.

The similar relationship has been checked by ut1lizing the sounding data on the Nilgata west beach. Fig. 17 compares the shoreline undulations, the positions of bar crests, the rise of bar, and the refraction coefficlents based on the wave period of 10 seconds and arrivine at right angles to the mean shoreline. From here is also derived roughly the same conclusion as that already obtalned on the Tokal beach, although the correspondence between the rbythms on the shoreline and the bar seems to have been largely obscured due probably to Eradual extension of counter-erosion structures in the vicinity of the jetty. (See Fig. 13-C) Fig. 18 further compares the same factors on the basis of recent soundings. Agreement between the shoreline and bar rhythms seems largely satisfactory except for the portion between $1-2 \mathrm{~km}$ which is protected by counter-erosion structures.

The evidences so far presented as well as our experiences with aerlal photographs emphasize that there exists a significant relationship between the rhythms of the longshore bars and of the shoreline confleurations. However, as we will see later, this is not a cause-and-effect relationship; they are both a continuation of other rhythms which are found to 1 ie on the off shore bot tom.

\section{RHYTHMS ON THE OFFSHOKE BOTTOM}

Fer Bruun has discovered an undulating $r$ hythm on the offshore bottom along the Danish North Sea coast which is spaced by about $1.5-3 \mathrm{~km}$ and distinguished in every respect from a mere irregularity. No other published study is available for reference on this subject, except for extensive blbliographies regarding the 
RHYTHMIC PATTERN OF LONGSHORE BARS RELATED TO SEDIMENT CHARACTERISTICS

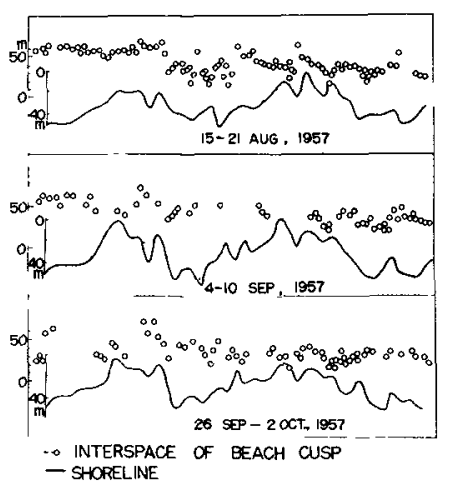

Flgure 16. Alongshore distribution of inter-apex size of beach cusp, reproduced from MOE1, Ref. 8 .

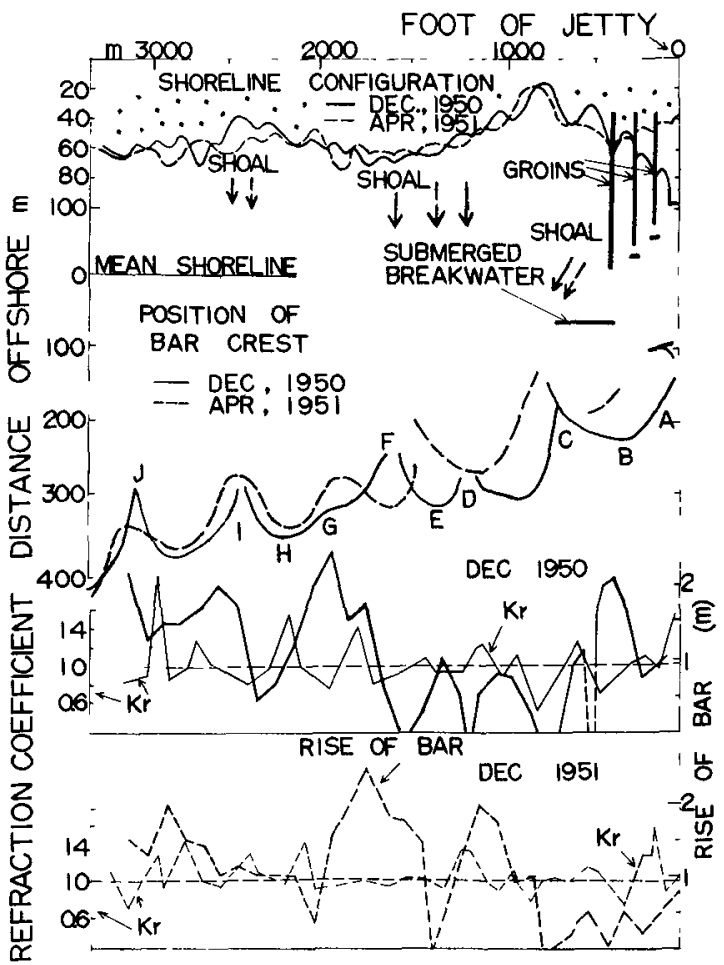

Flgure 17. Shoreline rhythms, bar rhythms and refraction coefficients compared for two consecutive years, Nilgeta west beach. (Cf. Fig. 19)
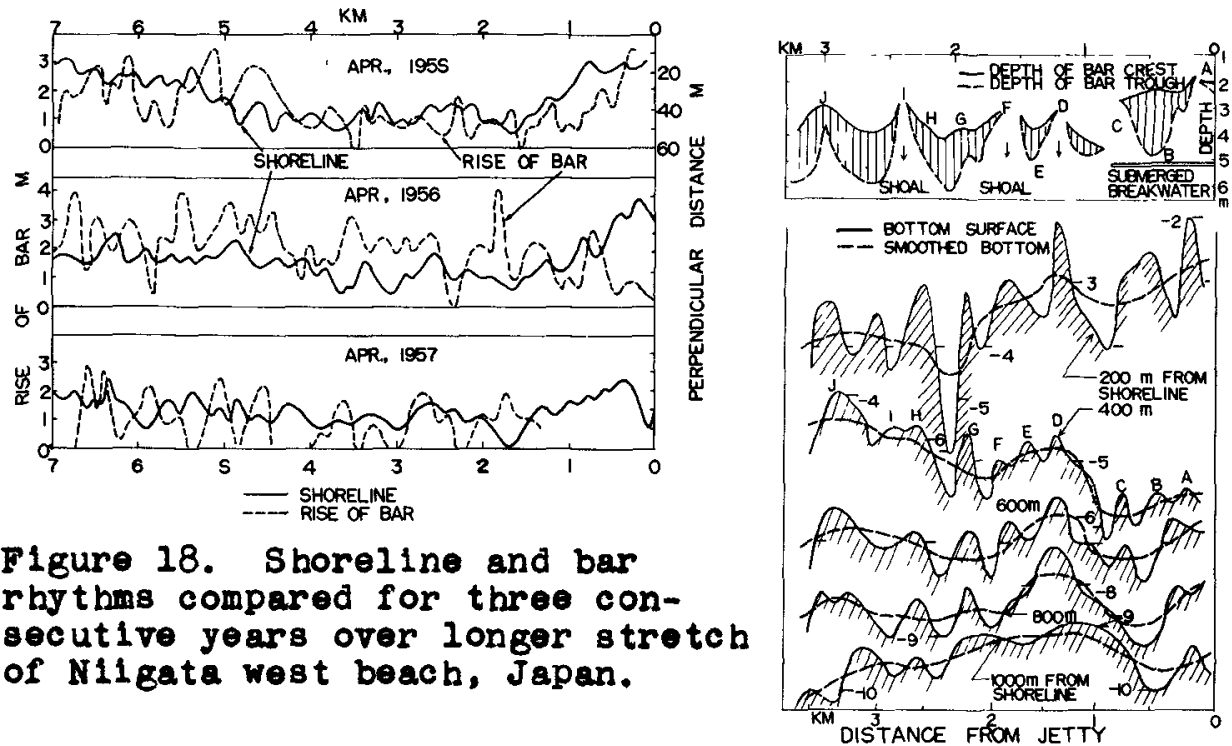

Figure 19. Rhytbmic undulations on of fshore bottom compared with bar topographies, shown in elevated view, Nilgata. (Cf. Fig. 17) 
submarine valleys whlch seem, however, to lie far beyond the scope of a shore process. Encouraged by his study, the present authors examlned the nature of such a glant $r$ bythm found on the of $f$ shore bottom in relation to other rhythms which have been already conflrmed to exist on the inshore bottom. The result bas been as jet too inconclusive to publish in a generalized form. However, some interesting features have been recognized.

F1g. 19 shows the elevated view of the bottom topographies of the N11gata west beach sounded in December, 1950. At about $1 \mathrm{~km}$ from the shoreline where the depth is about $10 \mathrm{~m}$ we notice a gentle undulation on the bottom spaced by about $1.5-2 \mathrm{~km}$ between adjacent ridges, which is overlapped by a smaller inconsplcuous rhythm of the order of about $30 \mathrm{Cm}$. As these $r$ hythms approach the shore, there is a general increase of the rlse of the rhythms not only in the mean trend ( $s$ hown by dotted curves) but also in the minute pattern due to occurrence of dendritic ridges and valleys. Thus, at the distance of $400 \mathrm{~m}$ from the shoreline, 1. $\theta$. Immedlately offshore of the bar crest, the entire bottom $1 \mathrm{~s}$ covered with slender ridges spaced by about $300 \mathrm{~m}$ on arerage.

We recognize a remarkable feature by comparing the positions of these ridges with the elevated view of the loneshore bars that each of the ridges is impressed on the bar topography. The ridge corresponds to a shallow crest and $a$ shallow trough, and where thls rldge or valley 18 pronounced - es $1 t$ is always so at the crest or trough of the mean bottom (dotted curves), respectively - there 1s a breaching of a bar, 1. $\theta$. a shoal. We further notice an important fact by comparing Fig. 19 with the shoreline conflguration as shown in our previous Fig. 17, that these of shore undulations are virtually impressed on the shoreline, 1.e. that there is an embayment behind a trough or valley and an apex behind a crest or ridge. (Compare alphabetical symbols attached in F1gs. 17 and 19.) Thls pattern has been 1llustrated by an ldeal sketch in Fig. 20.

Now, we reallze that the role of a longshore bar is limited merely to smoothing the undulating curve on the shoreline and unable to extingulsh completely the orlginal rhythmg which start at the offshore bottom. Th1s also explains why a shoreline rhythm occurs where there 1s no bar at all. In fact, the present authors have observed a number of such examples from gtudies of aerlal photographs on the Japanese coasts; a beach having a very steep bottom slope, exceeding 3 4 \% sometimes, 1s marked with shoreline rhythms where no bar is visible.

$$
\text { Questions remaln, however, as to the orlein of }
$$


RHYTHMIC PATTERN OF LONGSHORE BARS RELATED TO SEDIMENT CHARACTERISTICS

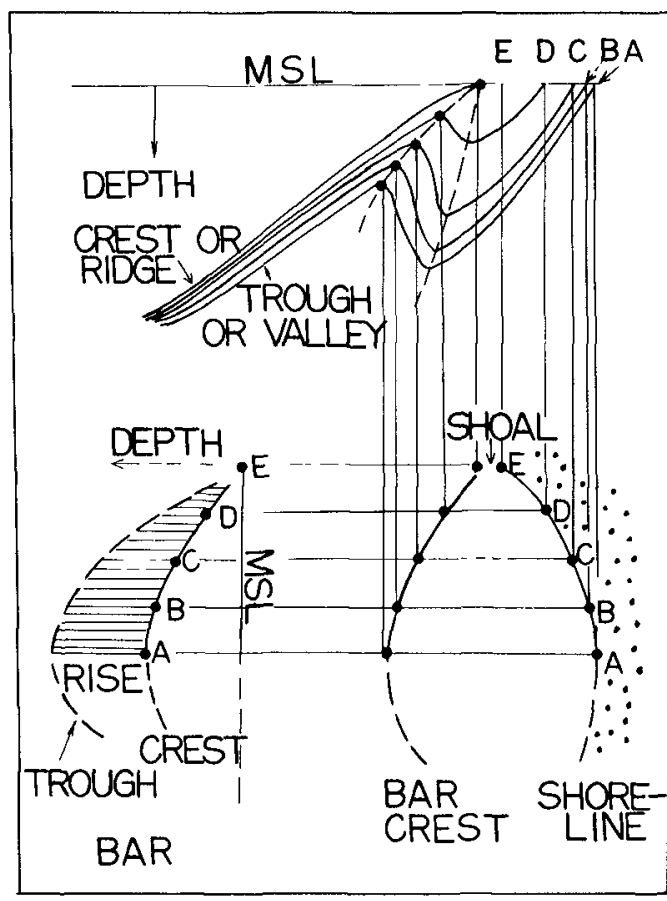

F1gure 20. Ideal correlation between undulating rhythms on off shore bottom, size and pos 1t1on of longshore bars, and shoreline rbythme.

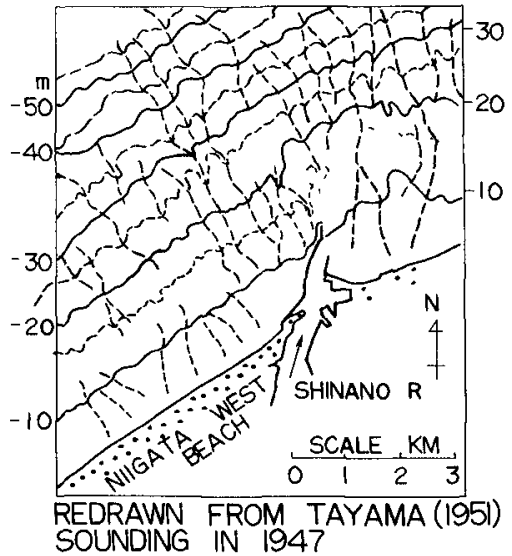

F1 gure 21. Submarine topoeraphy near shinano river outlet, reproduced from T. Tayama ot al (1951). Dotted curver Ind lcate courses of oubmarlne valleyo.

Figure 22. Shoreface olopes of Tokal beach, shown to retaln bas 10 rhythms.

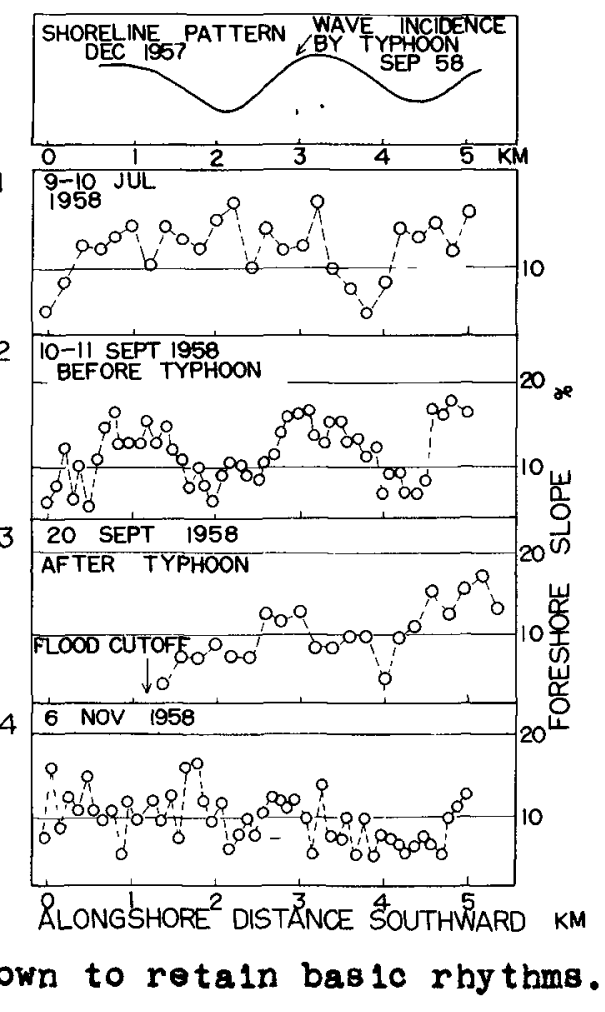


such an offshore undulation and also of 1 ts dendritic breaking pattern on the nearshore bottom. The present authors have not been successful in providing any recommendable answer to these questions. However, a tentative explanation has been attempted as follows. It is recalled that in an early section of this paper we have noticed a frequent occurrence of rhythmic bar patterng in the vicinity of a large river mouth. Usualiy, submarine valleys are found to occur in an appreciable number on the foreset slope of the submerged delta of a large river. According to our Fig. 21 , these valleys are spaced by about $1 \mathrm{~km}$ or so on the foreset bed of $f$ the mouth of the Shinano river, N1lgata. Some of them are traced a long way to the nearshore bottom, attainIng a depth of about $10 \mathrm{~m}$. If all the large undulat1ons whlch have been found on the offshore bottom could be a topography originating from the valleys of the foreset slope, it will follow that they are more or less a stationary feature. However, the accuracy of the avallable data prevents us from tracing every undulation found at a depth of $10 \mathrm{~m}$ as far away as the foreset bed where the depth $1 \mathrm{~s}$ approximately $25-30 \mathrm{~m}$. We must not go too far with an array of hypothesis which touches upon a fleld of the submarine geologists.

\section{MOVEMENT OF RHYTHS}

Both Dr. Bruun (Ref. 5) and Dr. Mogl (Ref. 8) seem to belleve that the shoreline rhythms migrate along the general direction of littoral drift. Interestingly enough, the rate of migration estimated by both authors are roughly congruous; $700 \mathrm{~m} /$ year in one instance and $0-1,000 \mathrm{~m} /$ year in general by Bruun, and $500-1,000$ m/year by Mogi.

However, if we compare the ahoreline conflgurations of the Tokal beach, Japan, measured by Mogl in 1956 and 57 ( $1 \mathrm{~g}$. $11-\mathrm{A})$, w1th that read off by the present authors from an aerlal photograph of 1961 (F1g. 12), it is realized that no substantial change has taken place on the shoreline rhythms over a period of $3-4$ years, for the fundamental phase patterns of these two data agree with each other surprisingly well, even though the latter involves errors due to wave swashes and tide levels which might have obscured the shoreline position appreciably. In fact, as Dr. Mogl polnts out, the shoreline rhythe migrated slightly between winter, 1956 and summer, 1957, but they resumed their original positions in summer, 1961, roughly three years later. This leads us to assume that the shoreline $r$ hythms may undergo a slight shifting and/or skewing movement under changing conditions of waves and currents, but not keep on migrating indefinitely at the rate suggested by these authors. 
The present authors have once interviewed an aggregate manufacturer in the Isbikawa Prefecture, Japan, who was engaged in exploiting beach gravels at an apex of a long shoreline rhythm which was spaced by about $1,000 \mathrm{~m}$. He claimed that the site had been there with the same stationary apex since he started this business several years ago. According to him, the apex had not moved to any marked degree in eltber direction alongshore, although an appreciable change was noticed in the perpendicular direction due to erosion or depos1tion by seasonal conditions of waves and currents. There is another evidence whlch seems to support the view of the present authors. In our previous Fig. 13-B a lone-term trend of shoreline regression is compared with the rhythmic undulation of the shoreline on the Nilgata west beach. The former has been averaged from the results of continuous surveys conducted for the past 10 - 20 years durlne which the trend of regression has been almost consistent in time though variable in position. We notice an excellent fit between the rate of regression and the ceneral rhythms of shoreline, 1. $\theta$. that the regression has always been intensive at the embayment but relatively slow at the apex of each rhythm which has a spacing of about $2,000 \mathrm{~m}$ on average. This seems to enable us to assume that the general trend of the large shoreline rhythms will remain virtually unchanged for at least a perlod of a decade or two.

On the other hand, we have not made any particular attempt to check the validity of the concept of "mlerating sand humps" on the off shore bottom as proposed by Dr. Bruun, owing partly to limitation of the accuracy of data on a deep bottom, and partly to the ceneral interruption of bottom topographles caused by the subsidence of the Nilgata area in recent years.

\section{OTHER MINUTE RHYTHMS}

\section{Shoreface slope}

Wo are familiar with the general topography of a small beach cusp where the shoreface is steep at the apex and gentle at the embayment. However, it is very hard to recognize this feature consistently with a medium rhythm of the order of $10^{2} \mathrm{~m}$. Frequently, the shoreface slope on both opposite sides of an appex may show a different trend. This scatter will be partly accounted for by the presence of a serles of small beach cusps and partly by the behavior of the beach at the time of measurement, 1.e. Whether it is progressing or retreating.

With the large rhythm of the order of $103 \mathrm{~m}$, however, $1 \mathrm{t}$ seems that the analogy of a beach cusp holds in general. According to our measurements at the Tokal 
beach (Fige. 22-1 - 22-4), the shoreface slope was oteep near the apex and gentle near the embayment, although there is a scatter due probably to a skewing pattern of the ohoreline rbythme or to alfference of exposure of each shoreline stretch. The most strikine feature in Figs. 22 is that this basic trend does not undergo a material change even if the beach is subjected to formidable action of typhoon waves which attain a belght of $5-7$ m at breaking. (Compare Fig. 22-2 and 22-3.)

\section{Beach deposit}

We have compared the measured shoreface slope with the median $\$ 12 \theta$ of deposit sampled at varlous foreshore levels between the etep and the upper berm on the Tokal beach. The results show a hopeless scatter except for one case in which the grain size of the step deposit has been used from the samples of September, 1958 (before typhoon). (F1g. 23) Our data have been smoothed (shown in dotted curves in Fig. 23) and replotted against the result of Bascom ( $R \oplus f .9$ ) in Fie. 24. It 18 recognized that the slope - erain $81 z \theta$ relationship 18 best defined where both factors best fit the shoreline $r$ hythms of the order of $2,000 \mathrm{~m}$. Also considering the fact that of all the levels on the foreshore the shoreIIne step is the place where the wave impact is most strongly displayed, we are inclined to presume that the shoreface slope is as subtly dependent on the wave impact as on the nature of deposit.

\section{DYNAMICAL FACTORS ASSOCIATED WITH BAR RHYTHMS}

\section{WAVES}

Over the nearshore bottom which undulates at regular rhythms, there will be a zonal convergence and divergence of incident waves due to refraction. In a three dimensional laboratory flume we of ten observe that a train of uniform waves are refracted and regrouped into separate fluxes having a finite crest length near the shallow water. Thls phenomenon seems to occur also in nature. We often encounter aerlal photographs which show separate groups of wave trains progresaing in the nearshore water almost at right angles to the shoreline. Juding from the crest patterns as observed on such photographs, this phenomenon 18 not always attributed to interference between two different trains of waves arriving from different generation areas.

We have constructed a refraction diagram by ut111zing a wave of 10 seconds arriving at right angles to the shoreline, and compared the refraction coefficients ur at the depth of $5 \mathrm{~m}$ with the ahoreline configuration 
and the longshore bars. (Fig. 17) The result is not fully convincine, malnly because the depth contours beyond $-10 \mathrm{~m}$ was not available in our data. However, if we take into consideration a relatively slight change of the value of $K_{r}$ at the positions $F, G, H$ and $I$, it is recognized that there is a good correlation between wave transformation and undulat ing bottom topographies. The waves converge at the undulating ridge or shoal where the crest of a bar sways toward inshore and becomes shallower, while it diverges at the undulating valley or the position of the pronounced rise of a bar where the bar crest sways toward offshore and becomes deeper. We may neglect the portion $A$ - $E$, since it is affected by artificial structures.

This relationship leads us to another interesting conclusion that a deep bar trough may not always be a result of high waves, for where such a deep trough, and hence a consplcuous bar having a large amount of rise, is found, the bar crest is also deep and the wave is diverged. A small wave breaking over a deep barrier may not be able to create a plunging action of sufficient violence which could account for such a deep trough as found in the center of a bar rhythm. It must be rather attributed to the influence of the offshore bottom topographies which are impressed continuously through the bar zone and in to the shoreline. Then, a question arises as to why we find only a small riso near the shoal area where a greater effect of wave impact is expected to occur by our conclusion. One of the most likely causes will be that the converging waves advancing alone this profile lose much of 1 ts enerey by partial breaking over the undulating ridge on the offshore bottom, to such an extent that by the time they reach the final breaking position near the bar zone the helght is reduced much lower than predicted by the theoretical refraction value. Another possible cause is ascribed to a surging action near the shoal which will result in smoothing of the bottom topography there. Whichever case it may be, it seems that a discrepancy of the local intensities of incident wave energies is obscured by the presence of an arcuate bar before they reach the shoreline.

Now a question arises as to how the littoral $r$ hythms can remain stationary against rapidiy changing conditions of wares. Is it possible that a particular type of littoral rhythms may represent a state of equilibrlum where the wax and wane of the nearshore topography is dellcately balanced against a particular type of waves 8 The present authors find it impossible to provide any promising clue to answer this extremely difficult yet vitally important question for the time being. However, as a helpful suggestion, an analogi- 


\section{COASTAL ENGINEERING}

cal example is drawn from our observation of the formation of a beach cusp which seems to correlate the stability conditions with the spectral properties of incident waves. The actual process of cusp formation is lllustrated in Fig. 25; the wave was a gentle swell of $0.5 \mathrm{~m} \mathrm{in}$ heleht and 8 seconds in perlod, arriving perpendicularly to the shoreline.

Stage 1. Backwash due to the preceding wave retards breaking of the following wave at the embayment, and breaking occurs prematuredly at the apexes.

Stage 2. Uprush at the apexes makes a two-thronged advance and a moment later a delayed breaking occurs at the embayment.

Stage 3. All the uprush begins to meet at the embayment. Impeded by flanking uprush from the apexes, that of the embayment is halted midway. Thus, a scarce amount of material is pushed upward from this part, whlle a relatively great amount of coarse material is carried up toward the summit of the apex.

Stage 4. All the uprushes clash at the center of the embayment causing a strong turbulence. Backwash starts toward offshore immediately thereafter, erodine the embayment and carrying fine material with them. Backwash gains in strength attaining a maximum momentum at the shoreline just where the followine wave is about to break. And the same process is resumed.

It is doubted whether a eroup of waves each possessing a distinguished wave period could produce the same of fect, for the backwash may be elther too early or too late to create the breaking pattern of Stage 1 , and consequently the succeeding stages will be largely interrupted. It seems necessary that the waves must have a relatively narrow optimum band of spectral frequencles in order to form a beach cusp. The shoreface slope w11l also count, since the time needed for the uprueb and backwash to conclude a cycle should colncide with the wave period.

It is questionable if this observation with a small beach cusp could be extended to a greater $r$ hythm of the order of $10^{2}$ or $10^{3} \mathrm{~m}$. However, on the other band, we realize that there exlsts a large-scale and long-perlod return of energy from the surf zone toward offshore in a manner of surf beat (having a time scale of 102 seconds) and $r i p$ currents, which represent a sporadic recompensation of the potential energles of the surf zone fed by the mass transport of the incident waves. Accordingly, our hypothesis is that there may 


\section{RHYTHMIC PATTERN OF LONGSHORE BARS \\ RELATED TO SEDIMENT CHARACTERISTICS}

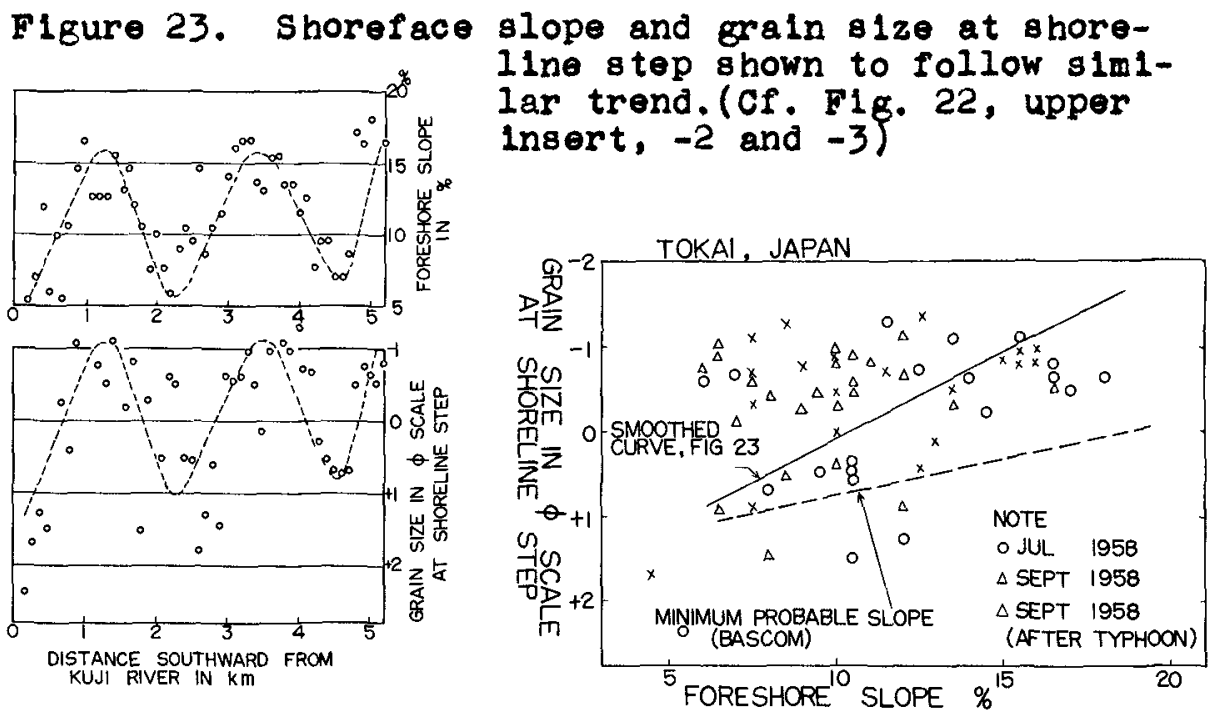

Figure 24. Grain s120-shoreface slope relationship compared w1th result of Bascom. (Cf. F1E. 23)
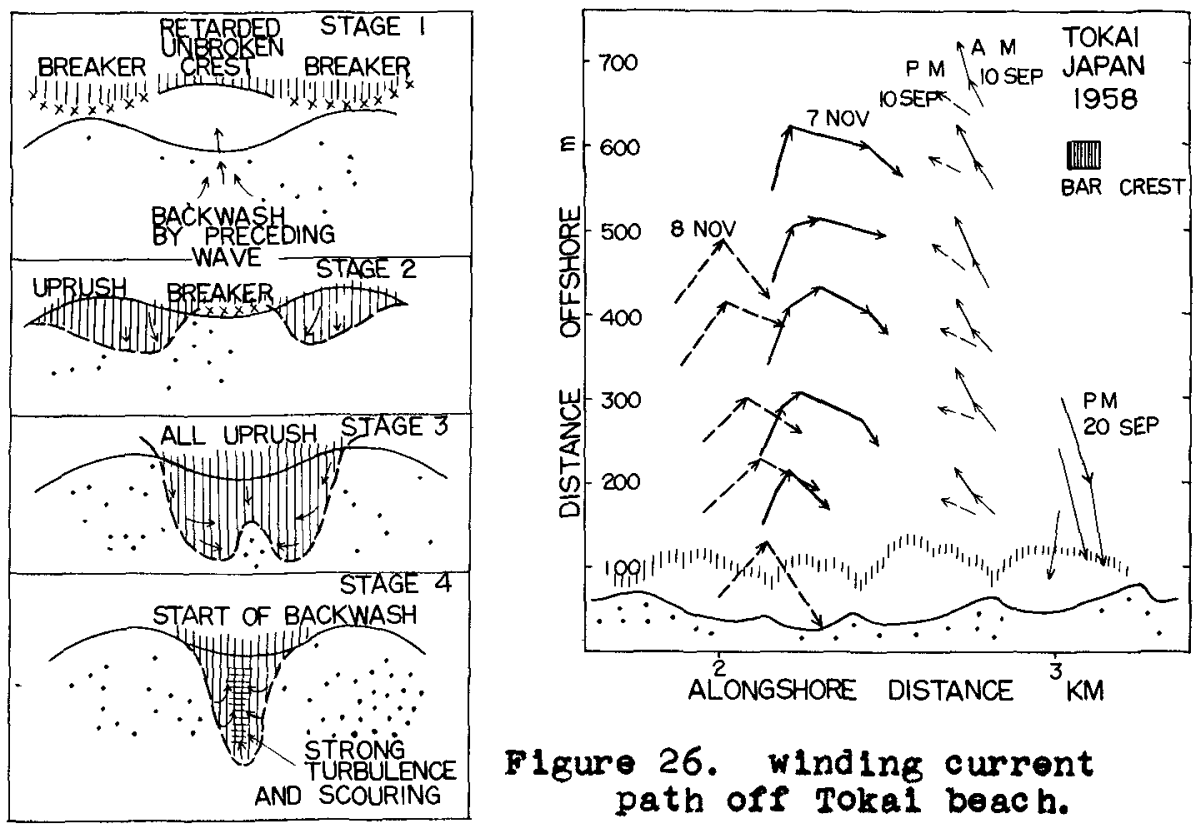

\section{Figure 26. winding current} path off Tokal beach.

$\because$ EXPOSED SHOREFACE $\times \times \times \times$ BREAKER

IIIIIIWAVE OR SWASH $\rightarrow$ SWASH DIRECTION

Fleure 25. Process of swash action at beach cusp, sketched on the basis of fleld observation. 
be a particular long-term set of wave spells having a well graded ensemble property of spectra which $18 \mathrm{com-}$ patible with the particular stability equilibrlum of a coast. However, there remain yet a number of other important questions which must be tackled before proceeding to answer ours.

\section{LONGSHORE CURRENTS}

According to our fleld investigation of longshore currents at the Tokal beach, the path of floats assumed a winding motion in space and time as they drifted along the shoreline. Fle. 26 shows some of such messurements, which were obtained by usine a current vane placed at $1 \mathrm{~m}$ below the sea surface. An interesting feature of these simultaneous paths of the floats is that they follow roughly a similar curve over the entire zone of measurement ranging from the shoreline to an offshore distance of about $600 \mathrm{~m}$ (about $8-9 \mathrm{~m}$ deep). The current velocities were very low at all times, mostly around $30 \mathrm{~cm} / \mathrm{sec}$.

On the other hand, we measured the alongshore components of current velocities by using the same type of float. (Fig. 27 A-F) Desplte that each run was carried out at different time and under different wave condit lons, we recognize a feature which ls largely common to al1 the measurements, that at an alongshore position of about $2.5 \mathrm{~km}$, the approximate position of a large shoreline embayment (See FlB. II-A.), there is always a sharp change of current velocities and occaslonally a complete reversal of direction, whlle near the positions of about $1 \mathrm{~km}$ and $3 \mathrm{~km}$, approximately the shoreline apex, the reverse currents seem to predominate.

An immediate conclusion which could be derived from the results of these measurements is that there seems to exist a rhythmic unit of current system which colncides with each position of embayment of the order of $10^{2}$ and $103 \mathrm{~m}$. This assumption has been lllustrated in an ideal picture in Fig. 28. According to this assumption, there exists an independent whirling current in the embayment of the shoreline, while there is a continuous current in the offshore water which winds gently in accordance with the intervals of the whirling eddies. Therefore, in front of the embayment where the alongshore components of the whirling current come in phase witb those of the of 1 shore current, the measured values are higher than those in front of the apex where two currents are often opposed. It seems as if the longshore currents consisted of a nearshore circulating system of winding currents and eddies which is more or less independent from the nelghbors and con- 

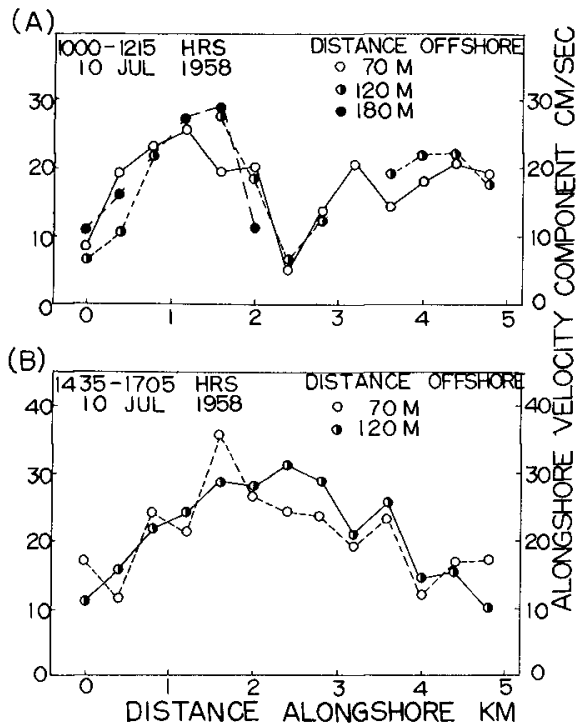

(E)

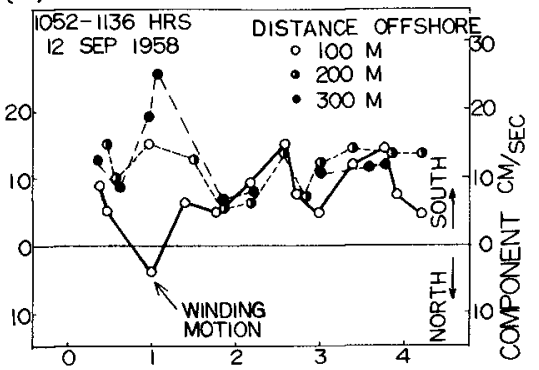

(F)

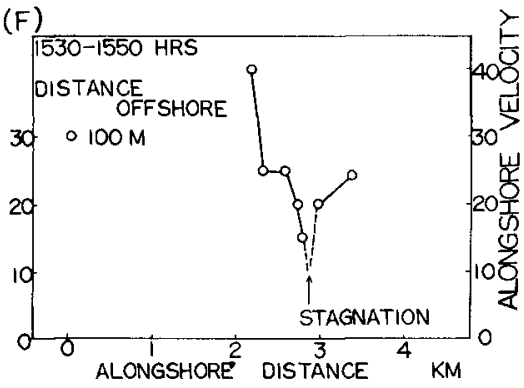

Figure 27. Distribution of elongshore velocity components, Toka1 beach, Japan.

Figure 29. Alongshore components of swash currents by typhoon waves measured at dif ferent positions of shoreline $r$ hy $\mathrm{thm}$, Sept. 1958, Tokal beach.
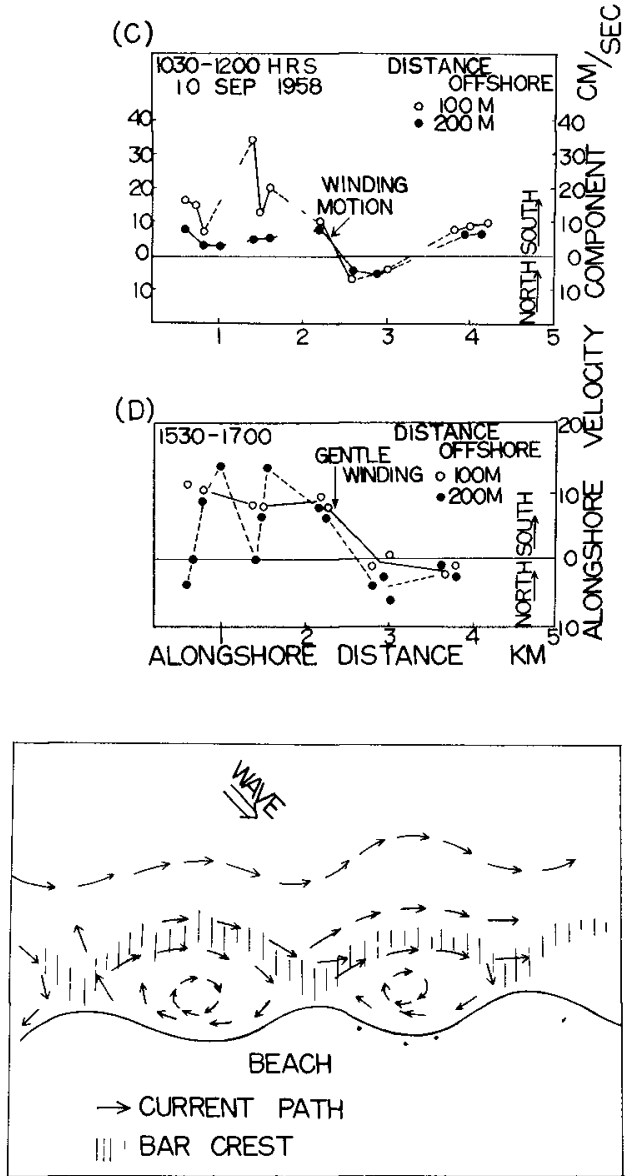

Figure 28. Ideal pattern of rhythmic circulation system shown to colncide with shoreline rhythm.
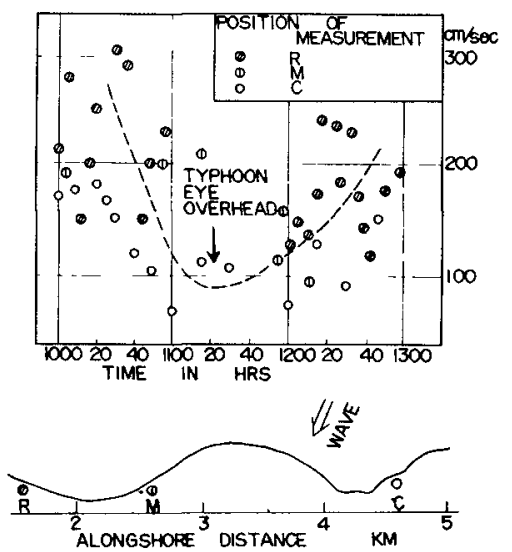


\section{COASTAL ENGINEERING}

fined in an embayment of the rhythmic undulation of the shoreline.

This ideal pattern of currents w11l undergo a change if the current velocities are intensifled. Flg. 29 shows an extreme case in which the alongshore components of swash currents were observed at the $\mathrm{shore-}$ line during the peak of typhoon waves. We st111 recognize the effect of the rhythmic confleuration of shoreline on the current pattern, 1.e. the currents are speedier at the place whlch 18 exposed to wave inc1dence $(R)$, while they are relatively low at the sheltered side of the shoreline apex ( $M$ and $C$ ).

\section{LONGSHORE DRIFT}

Slgniflcant drift of longshore sediment occurs mainly along the shoreline and the bar crest where the bottom deposit are easily set in suspension by agitating action of breakers. According to the observation of the authors, these two types of longshore drift seem to occur in a step-and-rest manner following the $r$ bythms on the shoreline and the bar.

In order to study the behavior of beach drift, the authors dumped brick fragments of about $16 \mathrm{~mm}$ in median diameter in front of a beach cusp on the Toka1 beach. The breaker helght was about $1-2 \mathrm{~m}$, and the current velocities ranged from 5 to $30 \mathrm{~cm} / \mathrm{sec}$. The drifting fragments were washed away to the shoreline step and none was found to return to the shoreface, whereas it is usually believed that beach drift along the shoreline occurs in a continual zig-zagging action on the shoreface slope. Interestingly enough, they were discovered at the updrift step of the downstream apex in an apprec1able quantity. Our explanation of this fleld experiment is that where there exists a consplcuous indentation of a beach cusp the beach drift w1ll move in a steppling flight from one apex to another in the direction of the longshore current rather than drageed on the shoreface where exchange of swash between the nelghbor ing embayments is hindered by $a$ steep rise of the intermediate apex. In connection with this, it is recalled that the famous Einstein bypothesis on the movement of bottom deposit in a twodimensional flow emphasizes on the rest time between flights of an individual erain. In the same analogy, 1t may be said in our case that the rate of beach drift along the shoreline will to some extent depend on the rest time of the bottom sediment on the updrift side of a beach cusp. However, we must think of a possibility that th1s ldeal pattern w1ll undergo a change, as has been the case w1th longshore currents, if wave cond 1tlons become more rigorous. Under such conditions, 


\section{RHYTHMIC PATTERN OF LONGSHORE BARS RELATED TO SEDIMENT CHARACTERISTICS}

a relatively stronger erosion will take place on the updrift side, producing a skew of the shoreline rhythm toward the downdrift direction.

In considering the littoral drift along the bar crest, it must be recalled that the longshore current takes a winding path roughly conforming the curvature of a loneshore bar. There is no reason why the bottom sediment on the bar crest should not be affected by this winding behavior of current and carried along the same curvature from shoal to shoal. This path is a lengthy detour involving an appreciable process of diffusion midway, but it may stili be relatively short as compared to the rest time during which the drifting sediment remain deposited at the shoal. Here again we are faced with the possibility of a rhythmic flight of littoral drift.

According to our hypothesis which has been discussed so far, we realize that it will be very difficult for the bottom sediment to travel perpendicularly across the surf zone between the shoreline and the longshore bar. In fact, as we have already seen, the embayment is a position which is most susceptible to erosion, or, in other words, a position where the drifting sediment will find it most difficult to arrive and settle. According to the observation of Dr. Mogi on the Tokal beach, when the beach was advancine the beach cusp occurred, but when 1t was retreating the beach cusp disappeared. It seems that only with appearance of $z$ beach cusp the embayment can arrest a sufficient amount of beach drift.

Our hypothesis regarding the rhythmic behavior of littoral sediment will further lead us to propose a detalled process on the perpendicular movement of the surf-zone sediment. The conventional notion is that a steep wave erodes the beach by carrying an appreclable amount of beach materlal toward the offshore bottom, which is, however, carried back to the beach by a subsequent swell of a low steepness. Our explanation is that if a swell predominates there will be a strong onshore drag of bottom deposit at the shoal due to violent sureing of refracted waves, thus giving rise to an increase in the portion of the beach drift as compared to the portion on the bar crest. On the other hand, if a strong wind wave predominates, there will be a reinforced component of of fshoreward recompensation of incldent energies in the form of a rip current or undertow, thus resultine in the increased portion of littoral drift alone the bar crest and in the relative decrease in the beach drift. In the latter case, the result will of ten be an erosion at the shoreline. 


\section{COASTAL ENGINEERING}

\section{SOME ENGINEERING IMPLICATIONS OF LITTORAL RHYTHMS}

Dr. Bruun states in effect that a sudden silting may occur at a coastal inlet due probably to migration of a shoreline hump or wave. This statement seems an adequate warning, and in the light of our theory it must be afforded more emphasis since such an accident might recur due to the same wave which would not migrate away at a noticeable rate. The authors are aware of a case where a sudden advance of a shoreline at a portion of the eroding beach was attributed to some mysterious action of a newly bullt sea wall. Although the authors have not had an opportunity to investigate the sounding data on the beach in question, it is highly probable from our theory that it is due to the shifting action of a shoreline rhythm. No positive action of a sea wall could bave been involved in this case.

The authors have been impressed, in reviewing a number of instances from aerial photographs, by an inadequately short length of coastal groins as compered to the distance of a longshore bar from the shoreline. However, in order to provide a workable design criterion on the functional specifications of groins or jetties, we will have to proceed further with a continuing effort to verify the hypothetical processes as tentatively proposed in the present paper with quantitative evidences.

The rhythmic distribution of wave impacts along the shoreline is also sometbing to take into consideration in designing a coastal structure. This point commands a particular welght when a structure, such as a submerged breakwater, is to be placed on the of $f$ shore bottom where waves will act without undergolng a smoothing action by a bar. Furtier, by considering the stationary nature of the littoral rhythms and hence of the alongshore distribution of wave impacts, we may specify the local strength of a sea wall or a unit welght of armor elements for each position within the rhythm phase. In fact, on the Nilgata west beach, the submerged breakwater was scoured by vlolent breakers and slumped from position to position. There is a sign that this failure pattern follows the undulation $r$ bythms on the offshore bottom, although we have not yet completed numerical checking on the detalls of this process.

However, the most immediate and valuable gain from recognizing the presence of stationary littoral rhythms is a possibility that we can shed light on the seemingly intractible process of a coast by introducing an orderly procedure of approach. We are in a position to treat the undulating topographies on the coastal feature as 


\section{RHYTHMIC PATTERN OF LONGSHORE BARS RELATED TO SEDIMENT CHARACTERISTICS}

important "factors", which in the past have been understood as mere irregularities.

Finally, the present theory will provide helpful suggestions in planning a coastal investigation project, namely in determining the factors and areal extent to cover and emphasize as well as the reasonable procedures of measurement and the adequate period of investigation.

\section{CONCLUDING REMARKS}

1. A careful investigation of nearshore topographies by aerial photographs as well as sounding data has shown that a rhythmic bar aystem is tied in closely with varlous rbythms found along the littoral zone.

2. These $r$ by thms are classified roughly into three different types of the order ranging from $10^{\mathrm{C}}$ to $103 \mathrm{~m}$.

3. These rhythms, represented in various factors such as longshore bars, shoreline conflgurations, deposit and slope of shoreface, waves and currents, have been found to originate at the undulations inherent to the offshore bottom.

4. The origin of such a large-scale rhythm on the offshore bottom as well as dendritic ridges or valleys on the inshore bottom, has been left for a future problem.

5. Several hypotheses have been presented as to the $r$ by thmic transformation of incident waves, rhythmic behaviors of littoral currents and drifts.

6. Recognition of the presence of stationary $r$ hythms on a coast ylelds useful suggestions regarding the engineering purposes.

\section{ACKNOWLEDGEMIENTS}

The authors have taken liberty of making extensive references to the existing contributions to the problems of coastal topography as well as the aerial photographs and sounding data by various agencies in Japan. A grateful appreciation is due to these authors.

Assistant Professor $K$. Horlkawa, Unlversity of Tokyo, has provided the authors with generous suggestions and cooperation during the course of preparing this paper. Misses I. Nurlno and R. Toyaku have been extremely helpful in preparing the figures of this paper. A profound gratitude of the authors is also 


\section{COASTAL ENGINEERING}

due to these people.

The authors remain profoundly grateful to Dr. M. Hoso1, Chief of Coastal Englneering Laboratory, Public Works Research Institute, Fublic Works Ministry, who has generously sponsored part of this project.

\section{REFERENCES}

1. Shepard, F. F. $(1 y 50)$. Longshore bars and longshore troughs, Beach Erosion Board, Tech. Memo. No. 15.

Shepard, F. P., K. O. Emery, and E. C. La Fond (1941). Rip currents; a process of geological importance, Journ. Geol., vol. 49.

2. Keulegan, G. H. (1948). An experimental study of submar ine sand bars, Beach Erosion Board Tech. Rep. No. 3 .

3. Fuj1ki, N. (1957). Instrumentation and accomplishments of the coastal investigation fac111ties for the winter stormy season at Nilgata, Proc. of $4 \mathrm{th}$ Conference of Coastal Engineering, Japan, (in Japanese).

4. Johnson, D. W. (191y). Shore processes and shoreline development.

5. Per Bruun (1954). M1grating sand waves and sand humps, with special reference to investigations carried out on the Danish North Sea coast, Proc. of 5tb Conference on Coastal Engine日ring.

6. Evans, 0. F. (1938). The classification and origin of beach cusps, Journ. Geol., vol. 46.

Evans, O. F. (1945). Further observations on the orlein of beach cusps, J. Sed. Petr., vol. 53.

7. Kuenen, Ph. H. (1948). The formation of beach cusps, Journ. Geol., vol. 56.

8. Mogi, A. (1960). On the topographical change of the beach of Tokaimura on the coast of Kanto district, Japan, Geographical Review of Japan.

9. Bascom, W. H. (1951). The relationship between sand $s 1 z e$ and beach-face slope, Trans. A. G. U., vol. 32 , No. 6 . 